\title{
Chicory increases acetate turnover, but not propionate and butyrate peripheral turnovers in rats
}

\author{
Etienne Pouteau*, Florence Rochat, Alfred Jann, Isabelle Meirim, Jose-Luis Sanchez-Garcia, \\ Kurt Ornstein, Bruce German and Olivier Ballèvre \\ Nestlé Research Centre, Nutrition and Health Department, Vers-Chez-Les-Blanc, PO Box 44, 1000 Lausanne 26, Switzerland \\ (Received 8 December 2006 - Revised 19 June 2007 - Accepted 29 June 2007)
}

Chicory roots are rich in inulin that is degraded into SCFA in the caecum and colon. Whole-body SCFA metabolism was investigated in rats during food deprivation and postprandial states. After $22 \mathrm{~h}$ of food deprivation, sixteen rats received an IV injection of radioactive ${ }^{14} \mathrm{C}$-labelled SCFA. The volume of distribution and the fractional clearance rate of SCFA were $0.25-0.27$ litres $/ \mathrm{kg}$ and $5.4-5.9 \% / \mathrm{min}$, respectively. The half-life in the first extracellular rapidly decaying compartment was between 0.9 and $1.4 \mathrm{~min}$. After $22 \mathrm{~h}$ of food deprivation, another seventeen rats received a primed continuous IV infusion of ${ }^{13} \mathrm{C}$-labelled SCFA for $2 \mathrm{~h}$. Isotope enrichment $\left({ }^{13} \mathrm{C}\right)$ of SCFA was determined in peripheral arterial blood by MS. Peripheral acetate, propionate and butyrate turnover rates were 29,4 and $0.3 \mu \mathrm{mol} / \mathrm{kg}$ per min respectively. Following 4 weeks of treatment with chicory root or control diets, eighteen fed rats received a primed continuous IV infusion of ${ }^{13} \mathrm{C}$-labelled SCFA for $2 \mathrm{~h}$. Intestinal degradation of dietary chicory lowered caecal $\mathrm{pH}$, enhanced caecal and colonic weights, caecal SCFA concentrations and breath $\mathrm{H}_{2}$. The diet with chicory supplementation enhanced peripheral acetate turnover by $25 \%(P=0.017)$ concomitant with an increase in plasma acetate concentration. There were no changes in propionate or butyrate turnovers. In conclusion, by setting up a multi-tracer approach to simultaneously assess the turnovers of acetate, propionate and butyrate it was demonstrated that a chronic chicory-rich diet significantly increases peripheral acetate turnover but not that of propionate or butyrate in rats.

Short-chain fatty acids: Chicory: Kinetics: Rats

Dietary fibres are fermented in the large intestine of man by anaerobic bacteria to produce SCFA, such as acetate, propionate and butyrate, and some gases ${ }^{1,2}$. SCFA are found in large quantities in portal vein blood after intestinal absorption and to a lesser extent in peripheral blood. Acetate is the most prominent SCFA in peripheral blood, it is favoured by most cells of the body as an energetic substrate and its oxidation contributes to about $7 \%$ whole-body resting energy expenditure in $\operatorname{man}^{3}$. All SCFA contribute to gut health and maintenance ${ }^{2,4}$ and may provide further benefits for peripheral metabolism ${ }^{1}$. The intestinal production of SCFA has been assessed in vitro $^{5}$, in in vivo animal models (pigs, dogs, rats) ${ }^{1}$ and also in human subjects 6 . Most studies have been limited to the determination of SCFA concentrations in biological fluids in animals and human subjects and only a few have investigated the peripheral turnover rate of acetate or of propionate ${ }^{3,7-9}$. To our knowledge no studies have investigated the peripheral turnover rates of propionate and butyrate after dietary fibre ingestion in either animals or human subjects.

The production of SCFA in the intestine occurs at a rate that depends upon the rate of entry of unabsorbed nutrients into the intestine and bacterial activity within the gut. It varies from a minimum during fasting, to a maximum several hours after dietary fibre ingestion and is dose dependent. After their production in, and absorption from, the gut SCFA are transported to the liver, where they combine with those produced endogenously during substrate metabolism. To our knowledge the endogenous production of propionate and butyrate is limited, but has not yet been evaluated. If it is possible to differentiate intestinal SCFA from those that are endogenously produced using labelling, one can estimate the intestinal production rate of SCFA (Fig. 1) ${ }^{10}$. The primary objective of the present study was to develop an isotope-dilution technique to determine whole-body SCFA turnover in a rat model. In a first experiment we investigated the kinetics of acetate, propionate and butyrate in whole-body peripheral circulation and in a second experiment we assessed their individual peripheral turnover rates in rats deprived of food for $22 \mathrm{~h}$. The second objective was to quantify in a third experiment the effect of 4-week chicory treatment on whole-body peripheral SCFA turnover in rats.

\section{Materials and methods}

Animals and diets

The animal experiments were approved by the Cantonal Committee for Ethics in Animal Experimentation (no. 1272;

Abbreviations: FCR, fractional clearance rate; IV, intravenous; MPE, mole percent excess; MRT, mean residence time; MS, mass spectrometry; Ra, rate of appearance; $T_{1} 1 / 2$, half-life of first phase (rapid decay); $T_{2} 1 / 2$, half-life of second phase (elimination decay); $V D$, volume of distribution.

* Corresponding author: Dr Etienne Pouteau, fax +41 2178585 44, email etienne.pouteau@rdls.nestle.com 


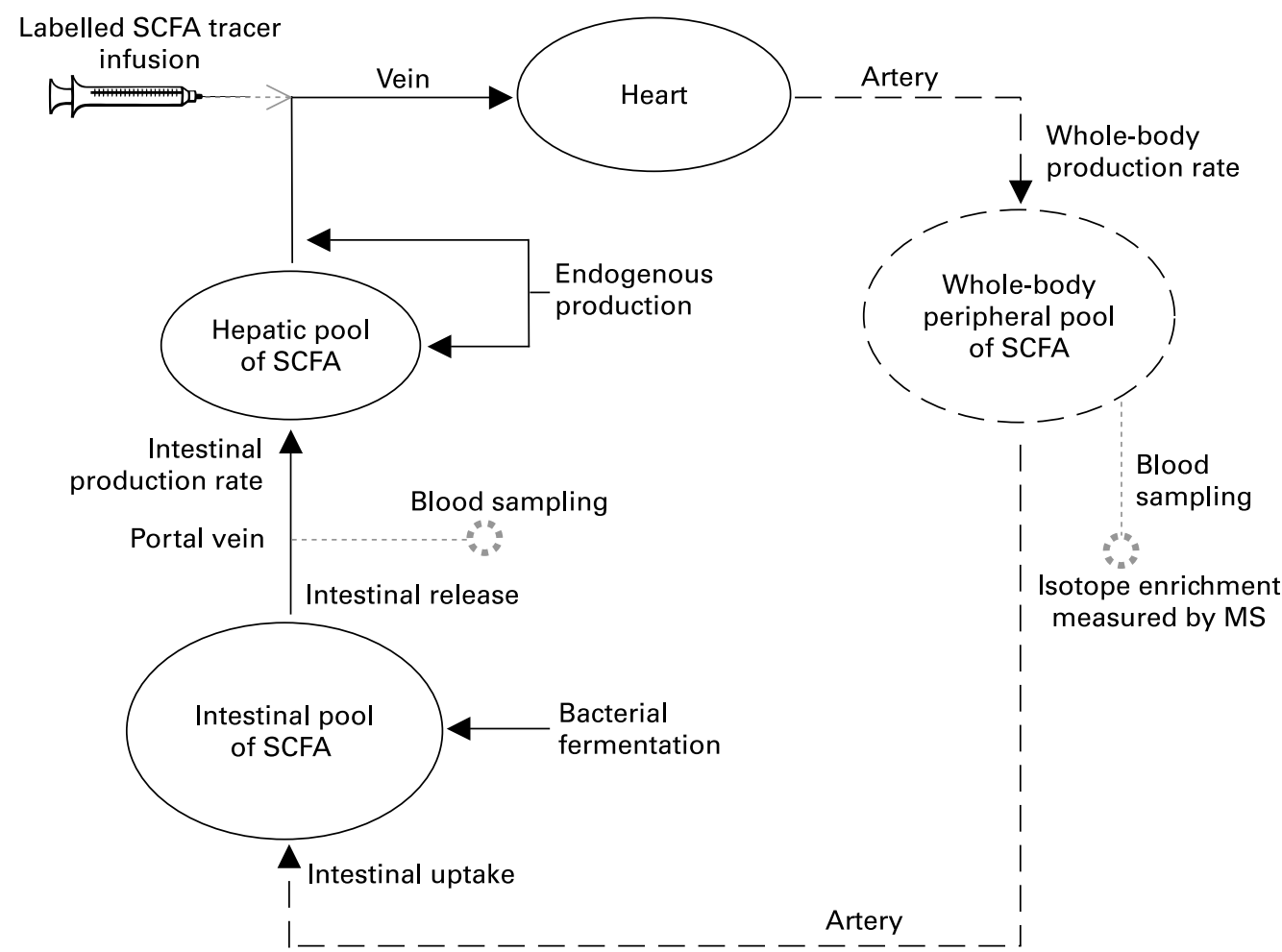

Fig. 1. Principle of using isotope-labelled SCFA intravenous infusions to investigate intestinal fermentation from peripheral metabolism of SCFA. Bacterial fermentation in the intestine produces SCFA that are transported through the liver to the peripheral blood circulation. The liver and whole body produce endogenous SCFA. From the isotope-dilution principle, the isotope enrichments in arterial blood reflect the whole-body SCFA turnovers that were estimated in food-deprived rats (Expts 1 and 2) and in the postprandial state (Expt 3 with control and chicory diets).

Service Vétérinaire, Etat de Vaud, Lausanne, Switzerland). Wistar rats were obtained from the Charles River Company (L'Arbresle, France). $\left[1-{ }^{14} \mathrm{C}\right]$ acetate, $\mathrm{Na}$ salt $(50 \mu \mathrm{Ci})$, $\left[1-{ }^{14} \mathrm{C}\right]$ propionate, Na salt $(250 \mu \mathrm{Ci})$ and $\left[1-{ }^{14} \mathrm{C}\right]$ butyrate, $\mathrm{Na}$ salt $(50 \mu \mathrm{Ci})$ were purchased from $\mathrm{NEN}^{\mathrm{TM}}$ Life Science Products, Inc. (Boston, MA, USA). $\left[1,2-{ }^{13} \mathrm{C}_{2}\right]$ acetate, $\left[1-{ }^{13} \mathrm{C}\right]$ acetate, $\left[1-{ }^{13} \mathrm{C}\right]$ propionate and $\left[1-{ }^{13} \mathrm{C}\right]$ butyrate $\mathrm{Na}$ salt tracers were purchased from Cambridge Isotope Laboratories (Andover, MA, USA). A conventional diet was used in experiments 1 and 2, which contained $23.5 \%$ protein, $5.5 \%$ fat, $52 \%$ carbohydrate and $3 \%$ fibre (Kliba 3310; Promivi Kliba SA, Kaiseraugst, Switzerland). The diets in experiment 3 were the same conventional diets enriched or not with $10 \%$ chicory (chicory dry root; Friskies SA, Amiens, France). The chicory was dry chicory roots composed of 50-60\% inulin, a non-digestible fructo-oligosaccharide. The chicory diet contained $8 \%$ fibre. The metabolisable energy of the diet was $14.0 \mathrm{~kJ} / \mathrm{g}$. The animals were adapted to the diet for at least 1 week before all experiments.

Rat model. A rat model was developed for intravenous (IV) tracer infusion and intra-arterial blood sample collection. The rat was anaesthetised with isoflurane (Baxter AG, Volketswil, Switzerland) for the duration of catheter insertion and tracer kinetics. Particular attention was taken to gently isolate the femoral vein and/or artery without injuring them. For all experiments, a catheter (24G Insyte; Becton Dickinson AG, Bale, Switzerland) was inserted into the femoral artery for blood sampling. For experiments 2 and 3, a catheter (24G Insyte) was also inserted into the femoral vein for tracer infusions. A first blood sample $(100-800 \mu \mathrm{l})$ was collected at time zero, in a heparinised tube, and was replaced by injecting the same volume of sterile saline solution $(0.9 \%$ $\mathrm{NaCl})$. Regular blood sampling $(800 \mu \mathrm{l})$ was possible as the sampling catheter was flushed with diluted heparin $(10 \%$ in saline solution) after each sample collection. Particular attention was taken to maintain body temperature constant under isoflurane anaesthesia. This rat model could be kept operational for $5 \mathrm{~h}$. At the end of the kinetic measurements, portal blood was eventually collected just before the rat was killed by exsanguination.

\section{Experiments}

Experiment 1. The experiment had a parallel design. Sixteen rats (eight males and eight females; weight $322.7 \pm 13.3 \mathrm{~g}$ ) were divided into three groups; one received the acetate tracer injection ( $n$ 5), another the propionate injection ( $n$ 6) and the other the butyrate injection $(n 5)$. Rats that were deprived of food for $22 \mathrm{~h}$ were submitted to kinetic studies in which either radiolabelled acetate, propionate or butyrate tracers were used (Fig. 1). The rats were anaesthetised, a catheter was inserted into the femoral artery and a first blood sample was taken at time zero $(100 \mu \mathrm{l})$. Each rat was injected with either $\left[1-{ }^{14} \mathrm{C}\right]$ acetate $(5.497$ (SEM 0.088) $\mu \mathrm{Ci}, 2.7483 \mu \mathrm{mol})$, $\left[1-{ }^{14}\right.$ C]propionate $(6.407$ (SEM 0.057$\left.) \mu \mathrm{Ci}, 0.1140 \mu \mathrm{mol}\right)$ or $\left[1-{ }^{14} \mathrm{C}\right]$ butyrate $(6.990(\operatorname{SEM} 0.007) \mu \mathrm{Ci}, 0.3548 \mu \mathrm{mol})$ in a randomised order. Arterial blood samples $(100 \mu \mathrm{l})$ were collected every $30 \mathrm{~s}$ until $5 \mathrm{~min}$, every $60 \mathrm{~s}$ until $10 \mathrm{~min}$ and at $12,14,16,18,20,25$ and $30 \mathrm{~min}$. The rats were then killed. The blood samples were analysed the same day. 
Experiment 2. The experiment had a parallel design. Seventeen rats (adult males; 389.1 (SEM 8.4) g) were divided into three groups; one received the acetate tracer infusion $(n 6)$, another the propionate infusion $(n 5)$ and the other the butyrate infusion $(n 6)$. Stable isotopes of acetate, propionate or butyrate tracers were used to determine their individual turnover rates in rats deprived of food for $22 \mathrm{~h}$ (Fig. 1). The catheters were inserted under anaesthesia and a first arterial blood sample was collected at time zero $(800 \mu \mathrm{l})$. Each rat received, intravenously, a primed continuous infusion of either $\left[1-{ }^{13} \mathrm{C}\right]$ acetate $(52.3$ (SEM 2.1) $\mu \mathrm{mol} / \mathrm{kg}$ and 0.98 (SEM 0.04$) \mu \mathrm{mol} / \mathrm{kg}$ per $\mathrm{min}$ ), $\left[1-{ }^{13} \mathrm{C}\right]$ propionate $(48.0$ (SEM 1.1$) \mu \mathrm{mol} / \mathrm{kg}$ and 0.97 (SEM 0.02$) \mu \mathrm{mol} / \mathrm{kg}$ per min) or $\left[1-{ }^{13} \mathrm{C}\right]$ butyrate $(49.7$ (SEM 1.9$) \mu \mathrm{mol} / \mathrm{kg}$ and 1.04 (SEM $0.05) \mu \mathrm{mol} / \mathrm{kg}$ per min) solubilised in $0.9 \% \mathrm{NaCl}$ sterile solution. Arterial blood samples $(800 \mu \mathrm{l})$ were collected at 60 , $75,90,105$ and $120 \mathrm{~min}$. A final blood sample was collected from the portal vein just before the rats were killed. All blood samples were centrifuged $(10 \mathrm{~min}$ at $1200 \mathrm{~g})$ and plasma stored at $-80^{\circ} \mathrm{C}$ until analysis.

Experiment 3. The experiment had a parallel randomised and controlled design. Eighteen rats (adult males; 378.2 (SEM $2.5 \mathrm{~g}$ ) were randomly divided into two groups; one received the chicory diet (chicory group; $n$ 10) and the other the conventional diet (control group; $n$ 8) for 4 weeks and stable-isotope kinetics were performed on the last day (Fig. 1). Food was not restricted the night before the kinetic studies. Each rat was fed by oral administration 1/12 of its daily intake of either the conventional or the chicory diet (according to their group assignment) every $30 \mathrm{~min}$ for $6 \mathrm{~h}$ in order to mimic continuous feeding. In the remaining time, each rat was placed in a 10 litre airtight transparent box for $12 \mathrm{~min}$ per $\mathrm{h}$ during the experiment to collect partially respired air. After the last feeding by oral administration, the catheters were inserted under anaesthesia and a first arterial blood sample was collected $(800 \mu \mathrm{l})$. Each rat was then administered, intravenously, a primed continuous infusion of $\left[1,2-{ }^{13} \mathrm{C}_{2}\right]$ acetate, $\left[1-{ }^{13} \mathrm{C}\right]$ propionate and $\left[1-{ }^{13} \mathrm{C}\right]$ butyrate simultaneously (all tracers solubilised in $0.9 \% \mathrm{NaCl}$ sterile solution; 287 (SEM 5), 97 (SEM 2) and 49 (SEM 1) $\mu \mathrm{mol} / \mathrm{kg}$ priming doses and 2.84 (SEM 0.04), 0.96 (SEM 0.01) and 0.48 (SEM 0.01) $\mu \mathrm{mol} / \mathrm{kg}$ per min infusion rates, respectively). Arterial blood samples $(800 \mu \mathrm{l})$ were collected at 60 , $75,90,105$ and $120 \mathrm{~min}$. A last blood sample was collected from the portal vein before killing. Mucosa samples from the caecum and the colon were obtained by scraping with a glass slide. Caecal and colonic contents and respective mucosal and non-mucosal intestinal tissues were collected and weighed. Intestinal contents and plasma were stored at $-80^{\circ} \mathrm{C}$ until analysis.

\section{Analysis}

Radiolabelled tracers. Blood samples were prepared for $\beta+$ radioactivity counting. Blood samples $(100 \mu l)$ were centrifuged and $40 \mu \mathrm{l}$ plasma were pipetted into a scintillation flask containing $20 \mathrm{ml}$ scintillant (Ultima Gold, Packard Bioscience Comp., the Netherlands). A scintillation counter (PerkinElmer ${ }^{\mathrm{TM}}$, Regendorf, Switzerland) measured and recorded $\beta+$ detection in counts per min. Data in counts per min were transformed into dpm accounting for quenching.
Stable isotope tracers. Measurements of $\left[1,2-{ }^{13} \mathrm{C}_{2}\right]$ acetate, $\left[1-{ }^{13} \mathrm{C}\right]$ acetate, $\left[1-{ }^{13} \mathrm{C}\right]$ propionate and $\left[1-{ }^{13} \mathrm{C}\right]$ butyrate enrichments and SCFA concentrations in plasma were performed as previously described ${ }^{11}$. Briefly, plasma samples $(450 \mu \mathrm{l})$ were spiked with $10 \mu \mathrm{l}\left[{ }^{2} \mathrm{H}_{3}\right]$ acetate internal standard. Samples were deproteinised with sulfosalicylic acid solution (10 $\mu \mathrm{l}, 1 \mathrm{~g} / \mathrm{litre}$; Fluka, Buchs, Switzerland) and centrifuged at $2200 \mathrm{~g}$ for $10 \mathrm{~min}$. The supernatant fraction was transferred into a vial containing $10 \mu \mathrm{l}$ hydrochloric acid (10 M) (Panreac, Barcelona, Spain), to which $3 \mathrm{ml}$ diethyl ether (99.8\%; Fluka, Buchs, Switzerland) were added. The vials were vortexed for $15 \mathrm{~min}$ and centrifuged for $10 \mathrm{~min}$ at $1200 \mathrm{~g}$, then $8 \mu \mathrm{l}$ tertbutyl-dimethyl-silyl-imidazole (Fluka Chemika, Buchs, Switzerland) were added to the separated organic phase. The sealed vials were heated to $60^{\circ} \mathrm{C}$ for $30 \mathrm{~min}$ after which they were cooled and evaporated to $200-300 \mu l$. Then $2 \mu l$ were injected into a gas chromatograph (model 5890A; Hewlett Packard, Palo Alto, CA, USA) connected to a quadrupole mass spectrometer (SSQ7000; Finnigan Mat, Bremen, Germany). Chromatographic separations were carried out with a $30 \mathrm{~m} \times 0.32 \mathrm{~mm}$ capillary column (DB5; J/W Scientific, Folsom, CA, USA) using the following temperature programme: initial temperature at $40^{\circ} \mathrm{C}$ for $1 \mathrm{~min}$, then $70^{\circ} \mathrm{C} /$ min up to $60^{\circ} \mathrm{C}, 10^{\circ} \mathrm{C} / \mathrm{min}$ up to $110^{\circ} \mathrm{C}$ and $70^{\circ} \mathrm{C} / \mathrm{min}$ up to $250^{\circ} \mathrm{C}$ for $1 \mathrm{~min}$. Ammonia chemical ionisation and selected ion monitoring were used on ions $\mathrm{m} / \mathrm{z}, 192,193$ and 194 for acetate, $\mathrm{m} / \mathrm{z} 206$ and 207 for propionate and $\mathrm{m} / \mathrm{z} 220$ and 221 for butyrate for isotope enrichment determination. Selected ion monitoring at $\mathrm{m} / \mathrm{z} 195$ was used for internal standard and concentration determination. Plasma concentrations were expressed in $\mu \mathrm{mol} / \mathrm{l}$ and isotope enrichments $\mathrm{M}_{0}+2$ and $\mathrm{M}_{0}+1$ in mole percent excess (MPE). Calibration curves for plasma concentrations showed excellent linearity from 1 to $1000 \mu \mathrm{mol} / \mathrm{l}$ for acetate, propionate and butyrate. Calibration curves for isotope enrichment $\left(\mathrm{M}_{0}+2\right.$ and $\mathrm{M}_{0}+1$ ) were linear from 0.5 to 99 MPE for $\left[1,2-{ }^{13} \mathrm{C}_{2}\right]$ acetate, $\left[1-{ }^{13} \mathrm{C}\right]$ acetate, $\left[1-{ }^{13} \mathrm{C}\right]$ propionate and $\left[1-{ }^{13} \mathrm{C}\right]$ butyrate ${ }^{11}$.

Caecal and colonic short-chain fatty acid analysis. SCFA concentrations in caecum and colon contents were measured using a method similar to that described earlier for plasma. Samples of faeces $(250 \mathrm{mg})$ were diluted in $1 \mathrm{ml}$ aqueous solution $\left(0.1 \% \mathrm{HgCl}_{2}, 0.1 \% \mathrm{H}_{3} \mathrm{PO}_{4}\right)$. The aqueous solution was homogenised by vortexing $(20 \mathrm{~min})$ and centrifuging $(5 \mathrm{~min}$; $1200 \mathrm{~g}$ ). Then $20 \mu \mathrm{l}$ hydrochloric acid $(32 \%)$ were added. Part of the upper liquid layer $(450 \mu \mathrm{l})$ was then extracted with diethyl ether $(3 \mathrm{ml})$. Thereafter, the sample preparation was identical to that described for plasma earlier. Analysis was performed using the same chromatographic conditions on another gas chromatograph-mass spectrometer (6890 Series; Hewlett Packard, Palo Alto, CA, USA) in electronic ionisation mode with selected ion monitoring at $\mathrm{m} / \mathrm{z}, 117$, $118,119,120$ and 131, 132, 133, 134 and 145, 146, 147, 148 and 149 for labelled acetate, propionate and butyrate, respectively ${ }^{11}$. SCFA concentrations in caecal contents were expressed in $\mu \mathrm{mol} / \mathrm{g}$ ( $\mathrm{g}$ of whole caecal content).

\section{Calculations}

Radiolabelled tracers. Radiolabelled $\left[{ }^{14} \mathrm{C}\right] \mathrm{SCFA}$ tracers were injected and distributed into a first pool from which tracers were rapidly eliminated into a second pool. A two-compartment 
modelling approach was used. The decay of $\left[{ }^{14} \mathrm{C}\right] \mathrm{SCFA}$ tracers (in dpm) as a function of time, $y(t)$, during kinetics was fitted by a bi-exponential curve using SigmaPlot (version 4.00) software $^{12}$. The equation of the fitting curve was:

$$
y(t)=A_{1} \times e^{-k_{1} \times t}+A_{2} \times e^{-k_{2} \times t}
$$

where $A_{1}$ and $A_{2}$ are constants (in dpm), and $k_{1}$ and $k_{2}$ are decay constants (in per min).

The rapid decay from the first pool is defined by:

$$
y_{1}(t)=A_{1} \times e^{-k_{1} \times t} \text {. }
$$

The elimination decay from the second pool is defined by:

$$
y_{2}(t)=A_{2} \times e^{-k_{2} \times t} \text {. }
$$

The values $A_{1}, A_{2}, k_{1}$ and $k_{2}$ were determined using a nonlinear least-squares estimation. This procedure determines the values that minimise the value for the residual sum of squares $(R S S)$, defined as:

$$
R S S=\sum_{i=1}^{n}(z(t)-y(t))^{2}
$$

where $z(t)$ are measured data at time $t, y(t)$ is the value at time $t$ derived from the equation to fit the data from $n$ number of samples per kinetic.

Constants $A_{1}$ and $A_{2}$ were thereafter first transformed into $\mu \mathrm{Ci}$, since it is known that $1 \mu \mathrm{Ci}$ equals $2.22 \times 10^{6} \mathrm{dpm}$, and further into $\mu \mathrm{Ci} / \mathrm{l}$ taking into account that $40 \mu \mathrm{l}$ plasma were analysed. From this curve fitting, the following parameters were calculated ${ }^{12}$ :

The area under the curve $(A U C$ in $\mu \mathrm{Ci} \times \min / 1)$ of the different $\left[{ }^{14} \mathrm{C}\right] \mathrm{SCFA}$ tracer decays:

$$
A U C_{0}^{\infty}=\frac{A_{1}}{k_{1}}+\frac{A_{2}}{k_{2}}
$$

where $A_{1}$ and $A_{2}$ are expressed in $\mu \mathrm{Ci} / 1$, and $k_{1}$ and $k_{2}$ in per $\min$;

The volume of distribution ( $V D$ in litres $/ \mathrm{kg}$ ) of the different SCFA, where SCFA are considered to be instantaneously and homogeneously distributed:

$$
V D=\frac{\text { dose }}{A_{1}+A_{2}} \times \frac{1}{W}
$$

where dose is the radiolabelled tracer dose injected (in $\mu \mathrm{Ci}$ ), and $W$ is the rat weight in $\mathrm{kg}$;

The fractional clearance rate $(F C R$ in $\% / \mathrm{min})$ of the different SCFA, the fractional rates at which SCFA are removed from $V D$ :

$$
F C R=100 \times \frac{A_{1}+A_{2}}{A U C_{0}^{\infty}}
$$

The total clearance ( $C$ in $\mathrm{ml} / \mathrm{min}$ ) of the different SCFA from $V D$ :

$$
\text { Total } C=F C R \times V D \times W \times 1000 \text {; }
$$

The mean residence time (MRT in $\min$ ) of the different SCFA in $V D$ :

$$
\begin{gathered}
M R T=\frac{\int_{0}^{\infty} t \times y(t) d t}{\int_{0}^{\infty} y(t) d t} \\
M R T=\frac{\frac{A_{1}}{k_{1}^{2}}+\frac{A_{2}}{k_{2}^{2}}}{\frac{A_{1}}{k_{1}}+\frac{A_{2}}{k_{2}}}
\end{gathered}
$$

The half-life of the first phase of the different SCFA, rapid decay from the first compartment $\left(T_{1} 1 / 2\right)$ (in $\mathrm{min}$ ):

$$
T_{1} 1 / 2=\frac{\ln (2)}{k_{1}}
$$

The half-life of the second phase of the different SCFA, elimination decay from the second compartment $\left(T_{2} 1 / 2\right)$ (in min):

$$
T_{2} 1 / 2=\frac{\ln (2)}{k_{2}}
$$

Stable-isotope tracers. The $\left[{ }^{13} \mathrm{C}\right] \mathrm{SCFA}$ tracers were continuously IV infused until an equilibrium was reached between the tracers and the whole-body SCFA production. The plateau values of isotope enrichment at steady state were equalled to the mean isotope enrichments during the last $30 \mathrm{~min}$ tracer infusion. Using the isotope-dilution principle ${ }^{13}$, the rates of appearance or turnover ( $R a$ in $\mu \mathrm{mol} / \mathrm{kg}$ per $\mathrm{min})$ of acetate, propionate and butyrate were calculated using the steadystate equation, as follows:

$$
R a=i \times\left(\frac{I E_{t}}{I E_{a}}-1\right)
$$

where $i$ is the IV infusion rate ( $\mu \mathrm{mol} / \mathrm{kg}$ per min) of $\left[{ }^{13} \mathrm{C}\right] \mathrm{SCFA}$ tracers, $I E_{t}$ and $I E_{a}$ are the $\left[{ }^{13} \mathrm{C}\right] \mathrm{SCFA}$ isotope enrichments of the tracer solution $\left(\left[1,2-{ }^{13} \mathrm{C}_{2}\right]\right.$ acetate, $\left[1-{ }^{13} \mathrm{C}\right]$ acetate, $\left[1-{ }^{13} \mathrm{C}\right]$ propionate or $\left[1-{ }^{13} \mathrm{C}\right]$ butyrate) and of arterial plasma at plateau, respectively, given in MPE.

The fractional extraction of the different SCFA by the intestine (\%extrac in \%) was as follows:

$$
\% \text { extrac }=100 \times \frac{\left(I E_{a} \times C_{a}\right)-\left(I E_{p v} \times C_{p v}\right)}{\left(I E_{a} \times C_{a}\right)}
$$

where $C_{a}$ and $C_{p v}$ are concentrations of SCFA, and $I E_{a}$ and $I E_{p v}$ are isotope enrichments of $\left[{ }^{13} \mathrm{C}\right] \mathrm{SCFA}$ at plateau in the femoral artery (a) and in the portal vein (pv), respectively. The utilisation or uptake of acetate, propionate and butyrate from intestinal tissues was evaluated assuming a blood flow in the portal vein of $15 \mathrm{ml} / \mathrm{min}$ (in $300 \mathrm{~g}$ rats) according to data from Jaeschke et al. ${ }^{14}$. Plasma flow was estimated (assuming $45 \%$ packed cell volume) to be $6.75 \mathrm{ml} / \mathrm{min}^{15}$, calculated as follows:

$$
\text { Uptake }=\% \text { extrac } \times C_{a} \times \text { plasma_flow }
$$

where 'plasma_flow' is expressed in litres/kg per min and was estimated from blood flow, packed cell volumes and rat body weight. 'Uptake' is expressed in $\mu \mathrm{mol} / \mathrm{kg}$ per min.

The production or release of acetate, propionate and butyrate from intestinal tissues was evaluated assuming a plasma flow in the portal vein as above. The following calculation 
was performed:

$$
\text { Release }=\text { uptake }+\left(C_{p v}-C_{a}\right) \times \text { plasma flow }_{-}
$$

where plasma_flow is expressed in litres $/ \mathrm{kg}$ per min and Release in $\mu \mathrm{mol} / \mathrm{kg}$ per min.

\section{Statistics}

Statistics were performed using Statistica (version $5.1 \mathrm{G}$ software; StatSoft Ltd, London, UK). One-way ANOVA were performed in experiment 1 between kinetic parameters of acetate, propionate and butyrate groups. Kinetic parameters were $A_{1}, A_{2}, k_{1}, k_{2}, V D, F C R$, total clearance, $M R T, T_{1} 1 / 2$ and $T_{2} 1 / 2$. One-way ANOVA was used in experiment 2 to compare parameters of the acetate, propionate and butyrate groups followed by a Tukey honest significant difference (HSD) test for unequal $n$ per group. Paired $t$ tests were performed in experiment 3 to compare SCFA concentrations between artery and portal vein and also to compare uptake and release from intestinal tissues. Unpaired $t$ tests were performed in experiment 3 to compare outcomes after the chicory diet treatment with those after the control diet. All data are presented as mean values with their standard errors. Differences were considered to be statistically significant at $P \leq 0 \cdot 05$.

\section{Results}

Experiment 1: Kinetic parameters of plasma short-chain fatty acids

The radiolabelled SCFA decays $\left(\left[{ }^{14} \mathrm{C}\right]\right.$ acetate, $\left[{ }^{14} \mathrm{C}\right]$ propionate and $\left[{ }^{14} \mathrm{C}\right]$ butyrate tracers) are shown in Fig. 2. Mean parameters of bi-exponential decays $\left(A_{1}, A_{2}, k_{1}\right.$ and $\left.k_{2}\right)$ and kinetic parameters are presented in Table 1 ; no significant differences were observed between acetate, propionate and butyrate. Distribution volumes were not significantly different; similarly no differences were observed for $F C R$, total clearance, $M R T$ and $T_{2} 1 / 2$ between the SCFA. Rapid decay half-life $\left(T_{1} 1 / 2\right)$ was not significantly shorter for acetate than for butyrate.

\section{Experiment 2: Turnover of plasma short-chain fatty acids}

The plasma isotope enrichments of $\left[1-{ }^{13} \mathrm{C}\right]$ acetate, $\left[1-{ }^{13} \mathrm{C}\right]$ propionate and $\left[1-{ }^{13} \mathrm{C}\right]$ butyrate reached a plateau during the last 30 min of each IV infusion (Fig. 3). Equal infusion rates of $\left[1-{ }^{13} \mathrm{C}\right]$ acetate, $\left[1-{ }^{13} \mathrm{C}\right]$ propionate and $\left[1-{ }^{13} \mathrm{C}\right]$ butyrate showed different plateau values of isotope enrichments at 3.5 (SEM 0.6), 22.0 (SEM 3.7) and 76.6 (SEM 3.6) MPE $(P<0.005)$, respectively. At the end of the IV infusions, no labelled acetate enrichment was detected in the portal vein, as opposed to labelled propionate (1.8 (SEM 0.6) MPE) and butyrate (7.3 (SEM 5.6) MPE). The turnover rates of acetate, propionate and butyrate in the whole-body peripheral circulation were 29 (SEM 4), 4 (SEM 2) and $0 \cdot 3$ (SEM 0.1) $\mu \mathrm{mol} / \mathrm{kg}$ per min, respectively in $22 \mathrm{~h}$ food-deprived rats (with $R a_{\text {acetate }}>$ $\left.R a_{\text {propionate }}>R a_{\text {butyrate }} ; P<0.0001\right)$.

\section{Experiment 3: Intestinal production of short-chain fatty acids}

The body weights of the rats increased during both 4-week diet treatments to 498 (SEM 8) g $(+32 \%)$ and 495 (SEM 9)
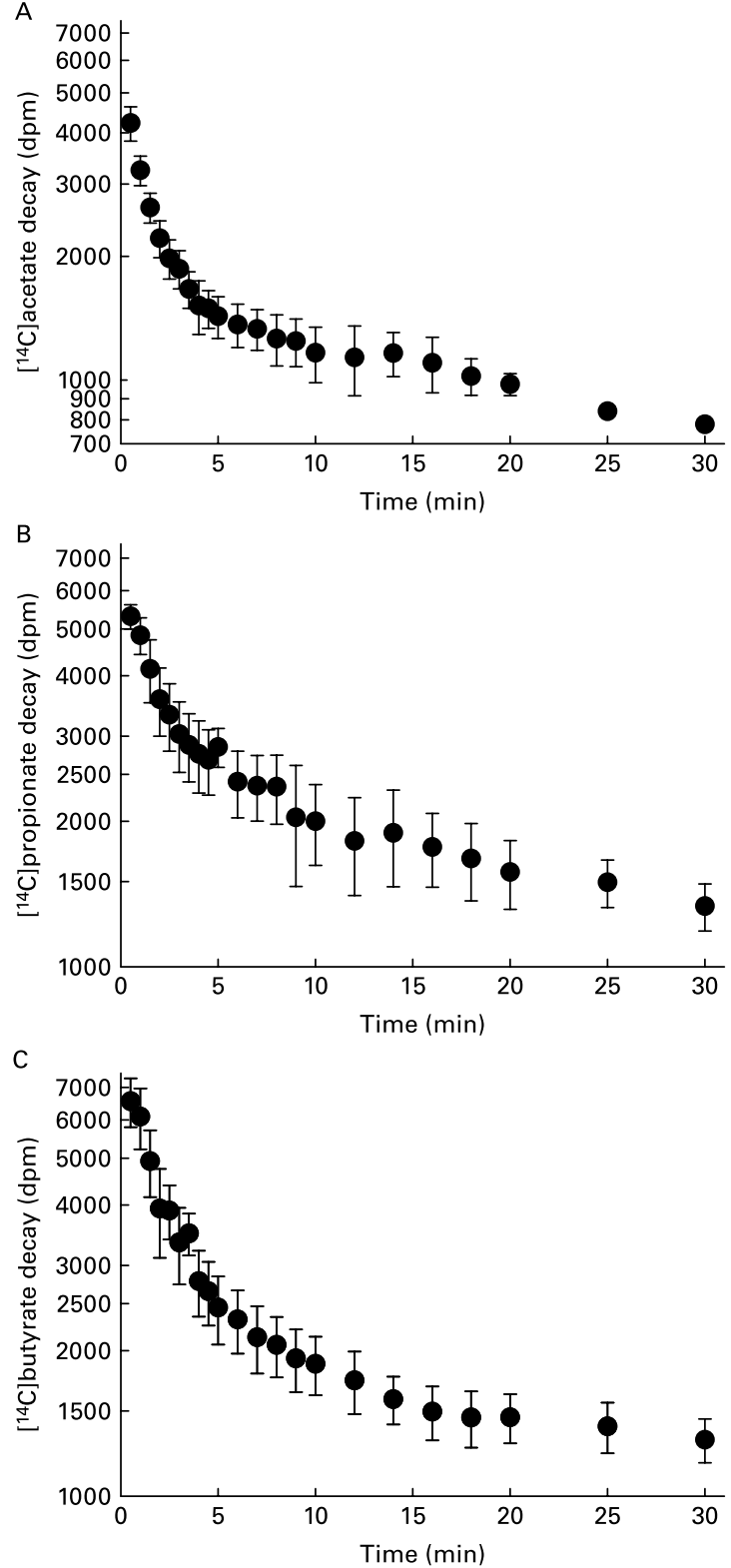

Fig. 2. Decays of the tracer plasma level (common log scale) used for biexponential curve fitting and kinetic parameter determination in adult rats that received $(\mathrm{A})$ a $\left[1-{ }^{14} \mathrm{C}\right]$ acetate, $(\mathrm{B})$ a $\left[1-{ }^{14} \mathrm{C}\right]$ propionate or $(\mathrm{C})$ a $\left[1-{ }^{14} \mathrm{C}\right]$ butyrate intravenous injection (Expt 1). Data are means, with their standard errors represented by vertical bars ( $n 5$ for acetate and butyrate tracer groups; $n 6$ for propionate tracer group).

g $(+31 \%)$, with no difference between the control and chicory diets, respectively. Food intake did not differ between the diet treatments (24 (SEM 1) g/d). The arterial concentrations of acetate were higher after the chicory than the control diet treatment $(P=0.026)$, but no difference was observed for propionate and butyrate (Table 2). The isotope enrichments of $\left[1,2-{ }^{13} \mathrm{C}_{2}\right]$ acetate, $\left[1-{ }^{13} \mathrm{C}\right]$ propionate and $\left[1-{ }^{13} \mathrm{C}\right]$ butyrate reached a plateau during the multi-tracer infusion (Fig. 4). The plateau isotope enrichments in arterial blood of $\left[1,2-{ }^{13} \mathrm{C}_{2-}\right.$ ]acetate were lower after chicory than after the control treatment $(P=0.025$; Table 2). No difference was observed between treatments in $\left[1-{ }^{13} \mathrm{C}\right]$ propionate isotope enrichment 


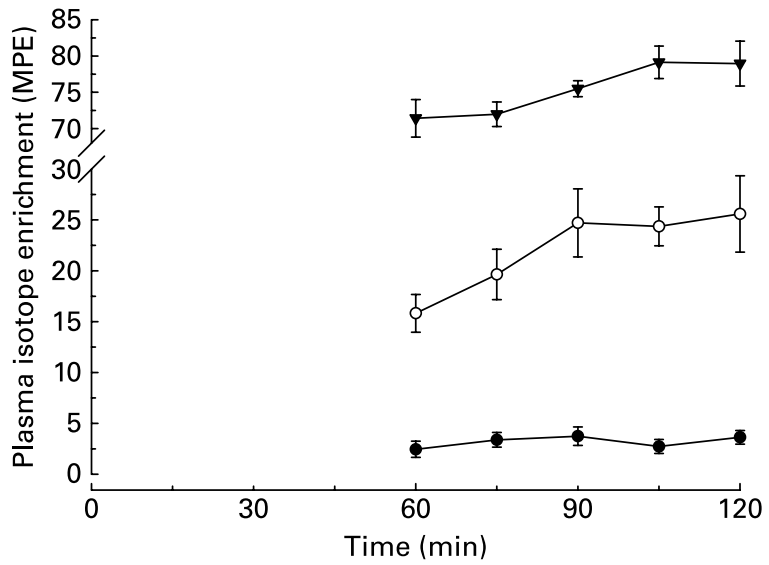

Fig. 3. $\left[{ }^{13} \mathrm{C}\right]$ isotope enrichments of acetate $(\bullet)$, propionate $(O)$ and butyrate ( $\mathbf{v})$ in arterial plasma during separate $\left[1{ }^{13} \mathrm{C}\right]$ SCFA primed continuous IV infusions in rats (Expt 2). Data are means, with their standard errors represented by vertical bars ( $n 6$ for acetate and butyrate tracer groups; $n 5$ for propionate tracer group). MPE, mole percent excess.

in arterial and portal vein blood (Table 2). No difference was observed in $\left[1-{ }^{13} \mathrm{C}\right]$ butyrate isotope enrichment in arterial blood. Portal vein $\left[1-{ }^{13} \mathrm{C}\right]$ butyrate enrichment was lower after chicory than after control diet treatment $(P=0.035$; Table 2). The $R a$ of acetate in the whole body was significantly higher after the chicory-enriched than after the control diet treatment $(P=0.017$; Table 2$)$. No difference was observed in the $R a$ of propionate and butyrate between diet treatments (Table 2). Intestinal extraction and rates of uptake and release of acetate, propionate and butyrate were not different between diet treatments (Table 3). The mean $\mathrm{pH}$ in the caecal lumen was lower in the chicory group (5.7 (SEM 0.1)) compared with the control group (6.0 (SEM 0.1); $P=0.017)$. Rats submitted to the chicory-enriched diet demonstrated a significant increase in whole caecal and whole colonic weights, as well as in empty caecal and empty colonic weights compared with those on the control diet $(P<0 \cdot 01$; Fig. 5). The caecal content was also significantly higher after the chicory diet, as well as non-mucosal colonic tissue weight $(P<0.05$; Fig. 5). Concentrations of acetate, propionate, iso-butyrate and iso-valerate were significantly increased in the caecal content after 4-week-chicory treatment compared with control treatment (Table 4), while concentrations of butyrate and valerate were not. The concentration of each SCFA evolved differently in the colon compared with the more proximal caecum; the colonic concentration of butyrate was decreased after chicory treatment compared with control treatment (Table 4). No methane was detected in expired breath in any of the rats. The area under the curve $(0-6 \mathrm{~h})$ of breath $\mathrm{H}_{2}$ was significantly higher in rats that consumed the chicory diet (176 (SEM 34) parts per million $\times \mathrm{h}$ ) compared with the controls (66 (SEM 6) parts per million $\times \mathrm{h} ; P=0.002$ ).

\section{Discussion}

Dry chicory roots contain about $50-60 \%$ inulin, which is a non-digestible fructo-oligosaccharide. The intestinal fermentation of inulin produces exogenous SCFA that mix with those produced endogenously ${ }^{16}$. We investigated the plasma kinetics 
Table 2. Concentrations, isotope enrichments and rates of appearance of plasma acetate, propionate and butyrate in arterial and portal vein blood in rats submitted to 4-week chicory or control diets (Expt 3)

(Mean values with their standard errors)

\begin{tabular}{|c|c|c|c|c|c|c|c|c|c|c|c|c|}
\hline \multirow{3}{*}{ Diet group... } & \multicolumn{4}{|c|}{ Concentrations $(\mu \mathrm{mol} / \mathrm{l})$} & \multicolumn{4}{|c|}{ Isotope enrichments (MPE) } & \multicolumn{4}{|c|}{ Rate of appearance ( $\mu \mathrm{mol} / \mathrm{kg}$ per $\mathrm{min})$} \\
\hline & \multicolumn{2}{|c|}{ Control (n 8) } & \multicolumn{2}{|c|}{ Chicory $(n 10)$} & \multicolumn{2}{|c|}{ Control ( $n$ 8) } & \multicolumn{2}{|c|}{ Chicory (n 10) } & \multicolumn{2}{|c|}{ Control ( $n 8)$} & \multicolumn{2}{|c|}{ Chicory ( $n$ 10) } \\
\hline & Mean & SEM & Mean & SEM & Mean & SEM & Mean & SEM & Mean & SEM & Mean & SEM \\
\hline \multicolumn{13}{|l|}{ Acetate } \\
\hline Artery & 287 & 22 & $352^{*}$ & 22 & $13 \cdot 0$ & 0.9 & $10 \cdot 6^{*}$ & 0.7 & $19 \cdot 7$ & 1.6 & $24 \cdot 7^{\star}$ & 1.5 \\
\hline Portal vein & 756 & 105 & 953 & 79 & $2 \cdot 4$ & 0.7 & 1.5 & 0.3 & - & - & - & - \\
\hline \multicolumn{13}{|l|}{ Propionate } \\
\hline Artery & 20 & 3 & 21 & 3 & $22 \cdot 7$ & $2 \cdot 8$ & $22 \cdot 6$ & $2 \cdot 3$ & $3 \cdot 8$ & 0.6 & 3.7 & 0.5 \\
\hline Portal vein & 148 & 37 & 172 & 31 & $2 \cdot 0$ & 0.6 & $1 \cdot 8$ & 0.2 & - & - & - & - \\
\hline \multicolumn{13}{|l|}{ Butyrate } \\
\hline Artery & 9 & 2 & 9 & 1 & $28 \cdot 8$ & 3.6 & $26 \cdot 5$ & 3.4 & $1 \cdot 3$ & 0.2 & 1.6 & 0.3 \\
\hline Portal vein & 237 & 72 & 238 & 58 & 1.6 & 0.6 & $0.6^{*}$ & 0.2 & - & - & - & - \\
\hline
\end{tabular}

${ }^{\star}$ Mean value was significantly different from that of the control group $(P<0.05)$.

and turnover rates of SCFA in food-deprived and fed rats (Fig. 1). Interestingly the peripheral turnover rates of propionate and butyrate were not negligible; however, a 4-weekchicory diet did not enhance their turnovers. We observed that a 4-week chicory diet increased intestinal fermentation and was accompanied by a $25 \%$ increase in peripheral acetate turnover in rats.

Non-ruminant models have been used to study SCFA production and metabolism ${ }^{1,17}$. Kien et al. evaluated butyrate turnover in piglets that received a $\left[{ }^{13} \mathrm{C}\right]$ butyrate infusion into the caecum ${ }^{17}$. While the rat model has been limited to the determination of SCFA concentrations in blood and intestinal contents $^{19-21}$, in the present study, an isotope approach was used to take into account the dynamics of SCFA metabolism. The radioisotope-tracer experiment, in the present study, did not reveal significant differences between SCFA kinetics in rats. As a consequence, we used the same $2 \mathrm{~h}$ infusion rate of different SCFA tracers to determine SCFA turnover rates in experiment 2. It appeared, however, that the SCFA had significantly different turnover rates when measured in the peripheral circulation, since the stable-isotope dilution method in experiment 2 is more accurate for turnover rate determinations. Consequently the last experiment, experiment 3 , was conducted using adapted priming doses and infusion rates of the different $\left[{ }^{13} \mathrm{C}\right] \mathrm{SCFA}$ tracers, by proportionally doubling the labelled acetate and lowering the labelled butyrate priming doses and infusion rates. A concomitant multi-tracer infusion technique was additionally developed in experiment 3 , which could be applicable in human subjects.

The study of SCFA plasma decays in experiment 1 revealed unique data on the plasma kinetics of the different SCFA. SCFA were rapidly cleared from the first pool (halflife $T_{1} 1 / 2<2 \mathrm{~min}$ ), which represents the whole-body extracellular volume, compared with the second, intracellular pool, which cleared much more slowly $\left(T_{2} 1 / 2=40\right.$ $65 \mathrm{~min}$ ). No significant differences in any of the plasma kinetic parameters of SCFA were observed, probably because their extracellular and intracellular distribution volumes are similar. The distribution volumes of the SCFA are very similar to those of glycerol $^{22}$ and acetate in dogs (0.27 (SEM 0.16) litres $/ \mathrm{kg})^{23}$. The turnover rate of acetate in the peripheral circulation of $22 \mathrm{~h}$ food-deprived rats was three times higher than that of human subjects in the post-absorptive state $(8.4$ (SEM $0 \cdot 6) \mu \mathrm{mol} / \mathrm{kg}$ per $\mathrm{min})^{3}$ and similar to that of $24 \mathrm{~h}$ fooddeprived dogs (24.4 (SEM 2.4) $\mu \mathrm{mol} / \mathrm{kg}$ per min) ${ }^{23}$. The turnover of propionate in $22 \mathrm{~h}$ food-deprived rats was higher than that $\left(0.6 \mu \mathrm{mol} / \mathrm{kg}\right.$ per min) reported by Sbaï et al. ${ }^{18}$ in metronidazole-treated human patients with propionic acidaemia and that $\left(0.3 \mu \mathrm{mol} / \mathrm{kg}\right.$ per min) reported by Walter et al. ${ }^{9}$ in four healthy human subjects. The use of different tracers and different species can probably explain these discrepancies. When the three experiments were compared, the following logical ranking was observed, $A_{\text {lacetate }}<A_{1 \text { propionate }}<$ $A_{1 \text { butyrate }}(\mathrm{NS})$ and $k_{\text {lacetate }}>k_{\text {lpropionate }}>k_{1 \text { butyrate }}(\mathrm{NS})$ in experiment 1 (Table 1), in parallel with $R a_{\text {acetate }}>$ Ra propionate $>R a_{\text {butyrate }}(P<0.05)$ in experiments 2 and 3 . The ranking of the different SCFA turnover rates was identical, but not proportional, to their plasma concentrations and is due to the fact that an increase in turnover rate is not necessarily accompanied by an increase in plasma concentration, especially when the $R a$ and rate of disappearance of the SCFA stays in equilibrium. This reinforces the relevance of the turnover determination in our experiments.

In experiment 3 , we observed a clear caeco-colonic fermentation of the non-digestible inulin component of the chicory diet. The rats consuming the 4-week chicory diet demonstrated, as expected ${ }^{24,25}$, a higher caecal and colonic weight, increased intestinal hypertrophy, higher SCFA concentrations in the caecum, a fall in $\mathrm{pH}$ and increased $\mathrm{H}_{2}$ concentrations in breath compared with those who consumed the control diet. Interestingly, in experiment 3 (Table 2) we observed that the acetate concentration in the portal vein was positively correlated with that in arterial blood $(r 0.62)$ and $R a$ of acetate $(r 0.56)$ and inversely correlated with acetate isotope enrichment in arterial blood $(r-0.62)$. Nonlabelled acetate, probably originating from the caecum, diluted the tracer and lowered the isotope enrichment after the chicory compared with the control diet. The Ra of acetate was also correlated with the acetate concentration in the caecum ( $r$ 0.63). The estimated release of acetate from the intestine (Table 3 ) was correlated with the $R a$ and with the concentration of acetate in the 

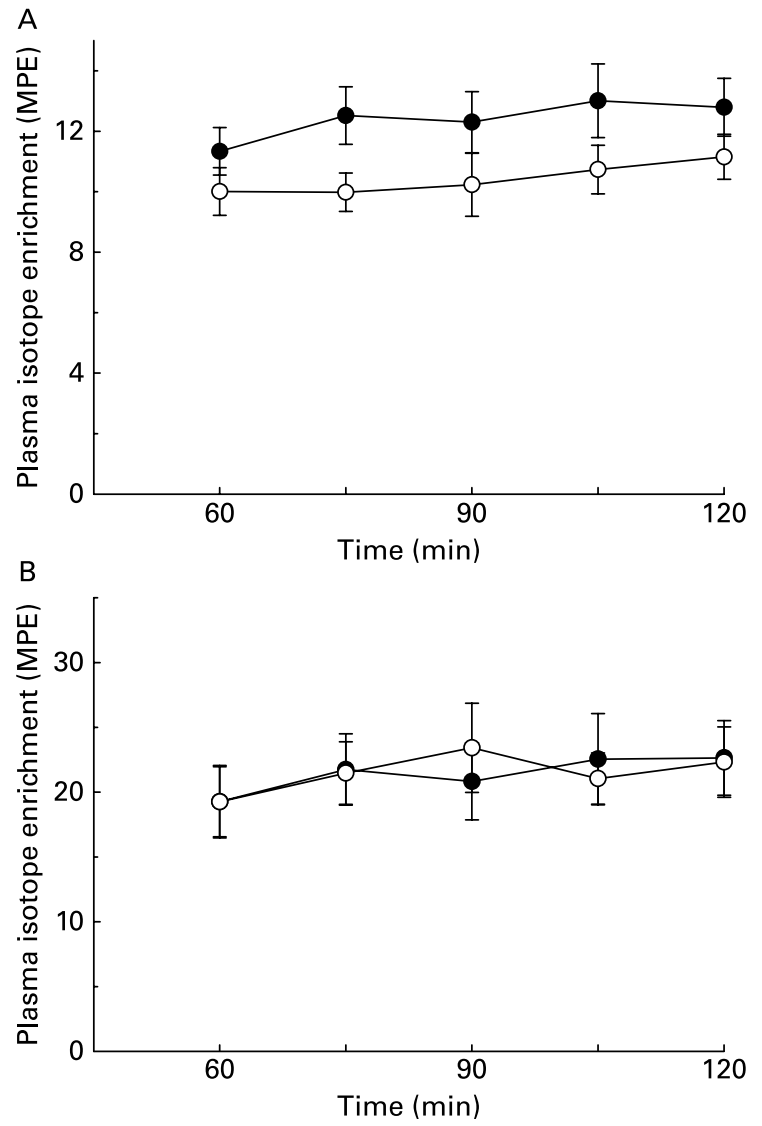

C

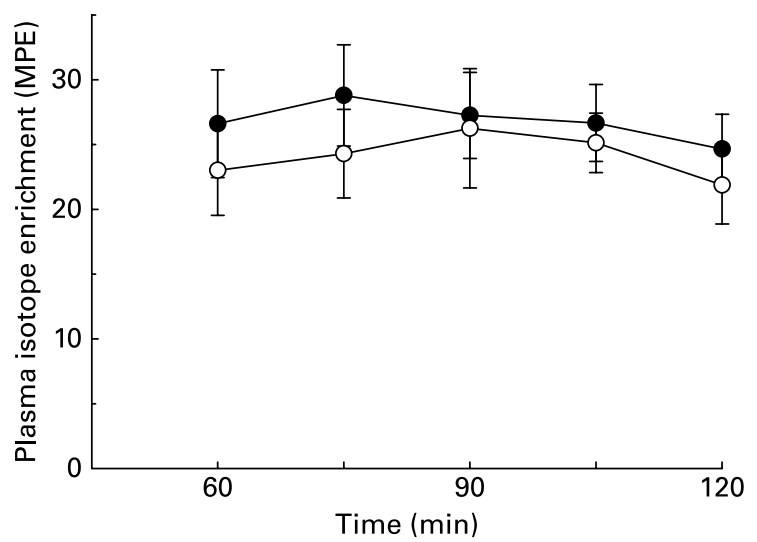

Fig. 4. Time-course of isotope enrichments of (A) $\left[1,2-{ }^{13} \mathrm{C}_{2}\right]$ acetate, (B) $\left[1-{ }^{13} \mathrm{C}\right]$ propionate and $(\mathrm{C})\left[1-{ }^{13} \mathrm{C}\right]$ butyrate in arterial plasma during simultaneous IV infusions of labelled acetate, propionate and butyrate in rats previously submitted to a 4-week chicory diet $(\bigcirc)$ or a 4-week control diet (•) (Expt 3). Data are mean values, with their standard errors represented by vertical bars.

peripheral circulation ( $r 0.50$ and 0.58 , respectively; Table 2 ). No such correlations could be observed for propionate or butyrate. However, a lower isotope enrichment of butyrate in the portal vein after chicory (Table 2) suggests that some non-labelled butyrate escapes mucosal uptake after its production in the intestine. A lower concentration of butyrate was observed in the colon after the chicory than after the control diet and was possibly due to a more efficient transport of SCFA through the gut barrier during fermentation.
In the present study we showed that acetate turnover increased by $25 \%$ in peripheral blood circulation, while propionate and butyrate turnover rates were unchanged in chicory-treated rats. In a previous study, dogs adapted to 3-week chicory intake showed a similar $31 \%$ increase in acetate turnover $^{26}$. In a previous clinical trial ${ }^{27}$, healthy adults that were submitted to an acute lactulose oral intake showed a sharp $63 \%$ increase in acetate turnover rate. No comparisons are available for propionate and butyrate turnovers to our knowledge. The present approach provides information about the net contribution of intestinal fermentation to peripheral metabolism, in terms of carbon flux available for either energy or for anabolic processes. Previous approaches using arteriovenous differences combined with a measure of blood flow provide similar information, however, with less accuracy. The latter, and tracer methods, have been thoroughly studied in ruminants ${ }^{28,29}$. Measurements of SCFA concentrations in the intestinal lumen or portal vein only provide static information about the production and absorption of SCFA at a particular moment in time ${ }^{30}$, and neglect the dynamic nature and physiological meaning of SCFA production rates. The present approach could have been improved by catheterising the portal vein to assess true SCFA production rates from the intestine in rats. Nevertheless, the present approach could be used in clinical research to measure SCFA turnover rates. SCFA turnover rates may differ in man and we cannot exclude, unlike acetate, that peripheral propionate and butyrate turnover rates can be beneficially modulated by consuming dietary fibres.

From the present, and previous studies, we have attempted to describe SCFA metabolism (Fig. 1). After absorption through the intestinal endothelial cells, SCFA are activated by enzyme acyl-CoA synthetase to serve as fuel for cellular energy or as an intermediate for intestine metabolism ${ }^{24,31-33}$. Following absorption, butyrate is activated to produce butyrylCoA. Butyrate is mainly metabolised in the colonocytes and is known to serve as a fuel for intestinal cells ${ }^{34}$. Acetate and propionate are absorbed and partially escape the filtering capacity of the intestine. Intestinal acetate release increased $30 \%$ into the portal vein, propionate release increased, but not significantly, while intestinal butyrate release did not increase after chicory ingestion in the present study. Independent of the diet, the liver retains most of the portal propionate and butyrate $^{35}$, where propionyl-CoA and butyryl-CoA are probably involved in gluconeogenesis and lipogenesis in hepatocytes $^{36,37}$. The non-negligible concentrations and turnover rates of propionate and butyrate were unchanged and constant in the post-hepatic circulation; these originate either from an endogenous production or from discrete amount of SCFA escaping the splanchnic filter. To a lesser proportion, acetate was retained and probably metabolised by the liver ${ }^{35,38}$. Considering that approximately $0.2 \mathrm{~g}$ inulin/h were reaching the rat hindgut, during the last trial, and taking into account the stoichiometric macrobiota degradation of inulin into SCFA after Roberfroid et $a l .{ }^{39}$, it is possible to theoretically estimate that approximately $50 \mu \mathrm{mol}$ acetate $/ \mathrm{kg}$ per min was produced in the gut. By comparing the chicory and control diet groups, the difference in acetate turnovers assessed in the peripheral circulation was about $5 \mu \mathrm{mol} / \mathrm{kg}$ per min; that is, only $10 \%$ of the theoretical caeco-colonic production. This suggests that a large amount of acetate is taken up and used by the splanchnic tissues in rats. The role(s) of such 
Table 3. Extraction, uptake and release of acetate, propionate and butyrate by intestine in rats submitted to 4-week chicory or control diets (Expt 3)*

(Mean values with their standard errors)

\begin{tabular}{|c|c|c|c|c|c|c|c|c|c|c|c|c|}
\hline \multirow[t]{2}{*}{ Diet group... } & \multicolumn{2}{|c|}{$\begin{array}{c}\text { Control } \\
(n 8)\end{array}$} & \multicolumn{2}{|c|}{$\begin{array}{c}\text { Chicory } \\
(n 10)\end{array}$} & \multicolumn{2}{|c|}{$\begin{array}{c}\text { Control } \\
(n 8)\end{array}$} & \multicolumn{2}{|c|}{$\begin{array}{c}\text { Chicory } \\
(n 10)\end{array}$} & \multicolumn{2}{|c|}{$\begin{array}{c}\text { Control } \\
(n 8)\end{array}$} & \multicolumn{2}{|c|}{$\begin{array}{c}\text { Chicory } \\
(n 10)\end{array}$} \\
\hline & Mean & SEM & Mean & SEM & Mean & SEM & Mean & SEM & Mean & SEM & Mean & SEM \\
\hline Acetate & 62 & 12 & 63 & 7 & $2 \cdot 5$ & 0.6 & $3 \cdot 2$ & 0.4 & $8 \cdot 6$ & 1.4 & $11 \cdot 3$ & $1 \cdot 1$ \\
\hline
\end{tabular}

${ }^{*}$ No significant differences were observed between the diets.

low-molecular-weight SCFA metabolites is still not fully understood. More investigations using stable isotopes would contribute to the understanding of the function of acetate, propionate and butyrate in whole-body energy metabolism.

In the present study, simultaneous IV infusions of labelled acetate, propionate and butyrate were used to determine the concurrent SCFA turnover rates in the peripheral circulation of rats. As much as $590 \mu \mathrm{mol}$ acetate/h was turned over in peripheral blood circulation, with turnover rates of 115 and $40 \mu \mathrm{mol} / \mathrm{h}$ for propionate and butyrate in food-deprived rats, respectively. Propionate and butyrate turnover rates appeared to be non-negligible and their role in systemic metabolism remains to be elucidated. The intestine and the liver probably play a role in the peripheral homeostasis of propionate and butyrate independently of non-digestible carbohydrate fermentation in the gut. Rats consuming a chicory diet for 4 weeks significantly increased peripheral acetate turnover but turnover rates of propionate and butyrate did not change when compared with rats on a control diet. Acetate constitutes an ideal marker of intestinal fermentation in rats. The present

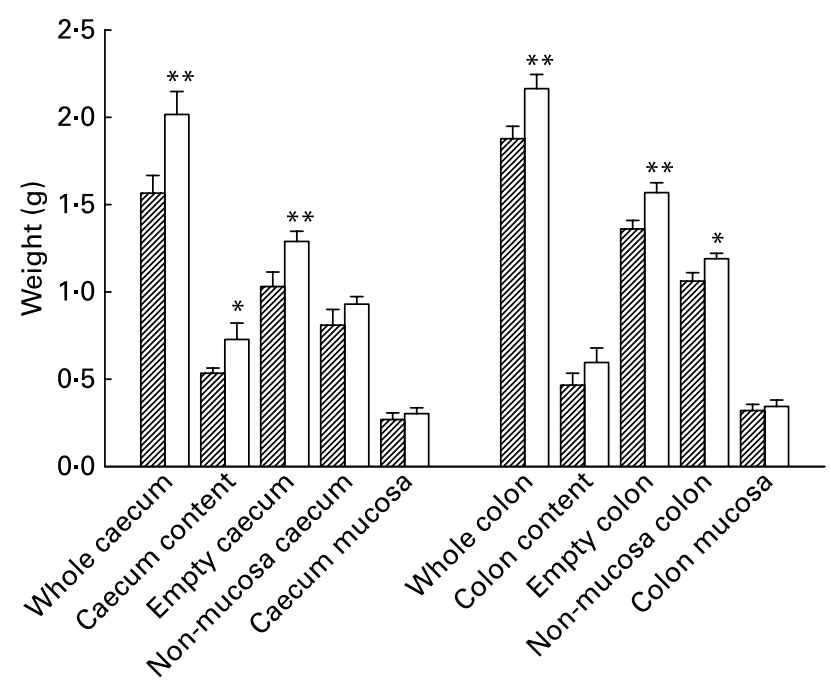

Fig. 5. Weights of whole organs, contents, empty organs, mucosa and nonmucosa tissues of caecum and of colon, respectively, of rats submitted to a 4-week chicory diet $(\square)$ or a 4-week control diet (何) in Expt 3. Data are mean values, with their standard errors represented by vertical bars. Mean value was significantly different from that of the control group: ${ }^{*} P<0.05$, ${ }^{\star \star} P<0.01$ (unpaired $t$ test).
Table 4. Concentrations ( $\mu \mathrm{mol} / \mathrm{g}$ whole content) of acetate, propionate and butyrate in the caecal and colonic contents of rats submitted to 4-week chicory or control diets (Expt 3)

(Mean values with their standard errors)

\begin{tabular}{|c|c|c|c|c|c|c|c|c|}
\hline \multirow{3}{*}{ Diet group... } & \multicolumn{4}{|c|}{ Caecum } & \multicolumn{4}{|c|}{ Colon } \\
\hline & \multicolumn{2}{|c|}{$\begin{array}{c}\text { Control } \\
(n 8)\end{array}$} & \multicolumn{2}{|c|}{$\begin{array}{c}\text { Chicory } \\
(n 10)\end{array}$} & \multicolumn{2}{|c|}{$\begin{array}{c}\text { Control } \\
(n 8)\end{array}$} & \multicolumn{2}{|c|}{$\begin{array}{c}\text { Chicory } \\
(n 10)\end{array}$} \\
\hline & Mean & SEM & Mean & SEM & Mean & SEM & Mean & SEM \\
\hline Acetate & 47 & 6 & $85^{\star *}$ & 10 & 39 & 5 & 44 & 5 \\
\hline Propionate & 14 & 2 & $22^{*}$ & 3 & 11 & 2 & 10 & 2 \\
\hline Iso-butyrate & 0.8 & 0.2 & $0 \cdot 2^{\star \star}$ & 0.1 & 0.5 & 0.1 & $0.1^{\star *}$ & 0.1 \\
\hline Butyrate & 46 & 6 & 56 & 6 & 25 & 5 & $16^{*}$ & 3 \\
\hline Iso-valerate & 0.9 & 0.3 & $0.2^{*}$ & 0.1 & 0.5 & 0.1 & $0.3^{\star \star}$ & 0.1 \\
\hline Valerate & 1.6 & 0.2 & 1.4 & 0.2 & 0.9 & 0.1 & $0.4^{\star *}$ & 0.1 \\
\hline
\end{tabular}

Mean value was significantly different from that of the control group:

${ }^{\star} P<0.05,{ }^{\star \star} P<0.01$.

quantitative determination of SCFA turnover rates after dietary fibre ingestion is applicable in human subjects and remains to be investigated.

\section{Acknowledgements}

The authors thank M. Gyger, S. N. Mafuala-Muana and M. Marchesini for their fruitful advice and assistance to perform the animal protocol. We thank Kevin Acheson for improving the writing style of the manuscript. Nestlé Research Centre financially supported the present study.

\section{References}

1. Bergman EN (1990) Energy contributions of volatile fatty acids from the gastrointestinal tract in various species. Physiol Rev 70, 567-590.

2. Mortensen PB \& Clausen MR (1996) Short-chain fatty acids in the human colon: relation to gastrointestinal health and disease. Scand J Gastroenterol Suppl 216, 132-148.

3. Pouteau E, Piloquet H, Maugeais P, Champ M, Dumon H, Nguyen P \& Krempf M (1996) Kinetic aspects of acetate metabolism in healthy humans using $\left[1-{ }^{13} \mathrm{C}\right]$ acetate. Am J Physiol 271, E58-E64.

4. Andoh A, Tsujikawa T \& Fujiyama Y (2003) Role of dietary fiber and short-chain fatty acids in the colon. Curr Pharm Des 9, 347-358. 
5. Barry JL, Hoebler C, Macfarlane GT, Macfarlane S, Mathers JC, Reed KA, Mortensen PB, Nordgaard I, Rowland IR \& Rumney CJ (1995) Estimation of the fermentability of dietary fibre in vitro: a European interlaboratory study. Br J Nutr 74, 303-322.

6. Cummings JH, Pomare EW, Branch WJ, Naylor CP \& Macfarlane GT (1986) Short chain fatty acids in the human large intestine, portal, hepatic and venous blood. Gut 28, 1221-1227.

7. Kien CL, Chang DH, Murray RD, Ailabouni A \& Kepner J (1990) Measurement of stable isotopic enrichment of underivatized acetate by gas chromatography / mass spectrometry: application to in vivo estimation of acetate production. Biol Environ Mass Spectrom 19, 554-558.

8. Mittendorfer B, Sidossis LS, Walser E, Chinkes DL \& Wolfe RR (1998) Regional acetate kinetics and oxidation in human volunteers. Am J Physiol 274, E978-E983.

9. Walter JH, Thompson GN, Leonard JV, Heatherington CS \& Bartlett K (1989) Measurement of propionate turnover in vivo using sodium $\left[{ }^{2} \mathrm{H}_{5}\right]$ propionate and sodium $\left[{ }^{13} \mathrm{C}\right]$ propionate. Clin Chim Acta 182, 141-150.

10. Pouteau E, Nguyen P, Ballevre O \& Krempf M (2003) Production rates and metabolism of short-chain fatty acids in the colon and whole body using stable isotopes. Proc Nutr Soc 62, 87-93.

11. Pouteau E, Meirim I, Metairon S \& Fay LB (2001) Acetate, propionate and butyrate in plasma: determination of the concentration and isotopic enrichment by gas chromatography/mass spectrometry with positive chemical ionization. J Mass Spectrom 36, 798-805.

12. Labaune JP (1987) Pharmacocinétique - Principes Fondamentaux. Paris: Masson.

13. Wolfe RR (1992) Radioactive and Stable Isotope Tracers in Biomedicine - Principles and Practice of Kinetic Analysis. New York: Wiley-Liss.

14. Jaeschke H (1992) Enhanced sinusoidal glutathione efflux during endotoxin-induced oxidant stress in vivo. Am J Physiol 263, G60-G68.

15. Rakusan K, Cicutti N \& Kolar F (2001) Cardiac function, microvascular structure, and capillary hematocrit in hearts of polycythemic rats. Am J Physiol 281, H2425-H2431.

16. Roberfroid MB (2005) Introducing inulin-type fructans. $\mathrm{Br} J$ Nutr 93, Suppl. 1, S13-S25.

17. Kien CL, Chang JC \& Cooper JR (2000) Butyric acid is synthesized by piglets. $J$ Nutr 130, 234-237.

18. Sbaï D, Narcy C, Thompson GN, Mariotti A, Poggi F, Saudubray JM \& Bresson JL (1994) Contribution of odd-chain fatty acid oxidation to propionate production in disorders of propionate metabolism. Am J Clin Nutr 59, 1332-1337.

19. Buckley BM \& Williamson DH (1977) Origins of blood acetate in the rat. Biochem $J$ 166, 539-545.

20. Vanhoof K \& De Schrijver R (1996) Effect of inulin on fermentation in rats and pigs. In COST 92 Action - Dietary Fibre and Fermentation in the Colon, pp. 275-279 [Y Mälkki and JH Cummings, editors]. Brussels: European Commission.

21. Adam A, Levrat-Verny MA, Lopez HW, Leuillet M, Demigne C \& Remesy C (2001) Whole wheat and triticale flours with differing viscosities stimulate cecal fermentations and lower plasma and hepatic lipids in rats. J Nutr 131, 1770-1776.

22. Beylot M, Martin C, Beaufrere B, Riou JP \& Mornex R (1987) Determination of steady state and nonsteady-state glycerol kinetics in humans using deuterium-labeled tracer. J Lipid Res $\mathbf{2 8}$, $414-422$.
23. Pouteau E, Dumon H, Nguyen P, Darmaun D, Champ M \& Krempf M (1998) Whole-body, peripheral and intestinal endogenous acetate turnover in dogs using stable isotopes. J Nutr 128, 111-115.

24. Juśkiewicz J, Glazka I, Król B \& Zduńczyk Z (2006) Effect of chicory products with different inulin content on rat caecum physiology. J Anim Physiol Anim Nutr (Berl) 90, 200-207.

25. Zdunczyk Z, Juskiewicz J, Wroblewska M \& Krol B (2004) Physiological effects of lactulose and inulin in the caecum of rats. Arch Anim Nutr 58, 89-98.

26. Pouteau E, Frenais R, Dumon H, Noah L, Martin L \& Nguyen P (2005) Colonic fermentation of inulin increases whole-body acetate turnover in dogs. J Nutr 135, 2845-2851.

27. Pouteau E, Vahedi K, Messing B, Flourie B, Nguyen P, Darmaun D \& Krempf M (1998) Production rate of acetate during colonic fermentation of lactulose: a stable-isotope study in humans. Am J Clin Nutr 68, 1276-1283.

28. France J \& Siddons RC (1993) Volatile fatty acid production. In Quantitative Aspects of Ruminant Digestion and Metabolism, pp. 107-121 [JM Forbes and J France, editors]. Wallingford, UK: CAB International.

29. Martin C, Kristensen NB \& Huhtanen P (2001) Comparison of non-tracer and tracer methods for determination of volatile fatty acid production rate in the rumen of sheep fed on two levels of intake. Br J Nutr 86, 331-340.

30. Fleming SE (1993) Influence of dietary fiber on the production, absorption, or excretion of short chain fatty acids in humans. In Handbook of Dietary Fiber in Human Nutrition, pp. 387-412 [GA Spiller, editor]. Boca, Raton, FL: CRC Press.

31. Kim M \& Shin HK (1998) The water-soluble extract of chicory influences serum and liver lipid concentrations, cecal shortchain fatty acid concentrations and fecal lipid excretion in rats. J Nutr 128, 1731-1736.

32. Levrat MA, Remesy C \& Demigne C (1991) High propionic acid fermentations and mineral accumulation in the cecum of rats adapted to different levels of inulin. $J$ Nutr 121, 1730-1737.

33. Knowles SE, Jarret IG, Filsell OH \& Ballard FJ (1974) Production and utilization of acetate in mammals. Biochem $J$ 142, 401-411.

34. Simpson EJ, Chapman MA, Dawson J, Berry D, Macdonald IA \& Cole A (2000) In vivo measurement of colonic butyrate metabolism in patients with quiescent ulcerative colitis. Gut 46, 73-77.

35. Remesy C, Demigne C \& Chartier F (1980) Origin and utilization of volatile fatty acids in the rat. Reprod Nutr Dev 20, $1339-1349$.

36. Wolever TM, Josse RG, Leiter LA \& Chiasson JL (1997) Time of day and glucose tolerance status affect serum shortchain fatty acid concentrations in humans. Metabolism 46, 805-811.

37. Zambell KL, Fitch MD \& Fleming SE (2003) Acetate and butyrate are the major substrates for de novo lipogenesis in rat colonic epithelial cells. J Nutr 133, 3509-3515.

38. Skutches CL, Holroyde CP, Myers RN, Paul P \& Reichard GA (1979) Plasma acetate turnover and oxidation. J Clin Invest 64, $708-713$.

39. Roberfroid M, Gibson GR \& Delzenne N (1993) The biochemistry of oligofructose, a nondigestible fiber: an approach to calculate its caloric value. Nutr Rev 51, 137-146. 